\title{
Acute respiratory effects in the potato processing industry due to a bioaerosol exposure
}

\author{
Albert Hollander, Dick Heederik, Henk Kauffman
}

\begin{abstract}
The relation between bioaerosol exposure in the potato starch industry and work related respiratory symptoms is described. One group of workers was exposed to high dust concentrations (geometric mean up to $56.0 \mathrm{mg} / \mathrm{m}^{3}$ ) with low endotoxin and antigen concentrations (geometric mean up to $12.6 \mathrm{ng} / \mathrm{m}^{3}$ and 90 relative antigen units (RAU) per $\mathbf{m}^{3}$ ). A second group was exposed to low dust concentrations (geometric mean up to $3.9 \mathrm{mg} / \mathrm{m}^{3}$ ), but the endotoxin and antigen concentrations were high (geometric means of environmental samples up to $72 \mathrm{ng} / \mathrm{m}^{3}$ and $2 \cdot 9.10^{2} \mathrm{RAU} / \mathrm{m}^{3}$ ). Twenty of the 48 workers had specific IgG $_{4}$ titres to dust extract. Of these 20 workers, 14 showed an increase in IgG $_{4}$ titre during the first month of the potato processing season. No specific IgE antibodies to dust extracts were found. Twenty two workers were equipped with a Mini-Wright peak flow meter during a four week period. Two workers showed a work related decline in peak flow values. It was concluded that exposure to dust made airborne during the refining process of potato starch may cause work related respiratory symptoms.
\end{abstract}

(Occup Environ Med 1994;51:73-78)

Airborne organic dusts and their biologically active constituents have been recognised as important factors leading to respiratory diseases in different working populations, such as farmers, laboratory animal workers, workers in animal feed plants, grain workers, and bakers. Inhalation of these dusts can cause a range of respiratory diseases: acute respiratory tract irritation, chronic bronchitis, hypersensitivity pneumonitis, and asthma and related toxin fever, accompanied by similar respiratory symptoms. ${ }^{1-5}$ Components that cause these diseases originate from different sources, such as animal dander, insects, mites, fungi, pollen, plant parts, and bacteria and their degradation products.

Recently, occupationally induced respiratory complaints have been found among workers in the sugar beet processing industry. ${ }^{6}$ Here, high concentrations of bioaerosols were the cause. Similar complaints were reported in a plant producing potato starch. Some workers employed in this plant reported work related wheeze and chest tightness to the physician of the occupational health service.

Occupational exposure to organic dusts may result in a hypersensitivity pneumonitis, characterised by raised IgG antibody titres against the organic dusts. Mechanisms mediated by IgE, however, are not excluded and have been noted among housewives exposed to potato allergens. ${ }^{78}$ Asthmatic reactions were precipitated by scraping potatoes before cooking, resulting in complaints of the upper and lower airways, like sneezing or wheezing. In our study it was therefore assumed that exposure to bioaerosols was the major factor leading to the work related wheeze and chest tightness reported by some of the workers. Exposures to bioaerosols were characterised by quantification of antigen and endotoxin concentrations. Health effects were characterised by registering prevalence of respiratory symptoms, specific IgE and $\operatorname{IgG}_{4}$ antibody concentrations against the airborne contaminants, and peak flow responses. The study comprised workers involved in all processes in potato starch production.

\section{Materials and methods}

PROCESS

Potatoes consist of water $(76.4 \%)$, starch $(17 \cdot 8 \%)$, fibres $(1 \cdot 3 \%)$, protein $(1 \cdot 2 \%)$, and other dissolved components (3.3\%). The first step in the process is to wash and grind potatoes and separate solid components from the fruitwater. Subsequently the starch is separated from the fibres by sieving. The starch is refined, dried, and stored for further use or shipment. Other components of the potato are further processed as well. Fibres are dehydrated, protein is extracted from the fruitwater by denaturation and dried, and other dissolved components are obtained by damping the fruitwater and mixing with soya hulls (protapec). These products are sold as raw materials for animal feed production.

Potato processing (campaign) starts in August and continues until April. During this period the factory is in continuous operation, processing about $90000 \mathrm{~kg}$ of potatoes/hour. Measurements were carried out at the beginning of the campaign during a four week period.

DUST SAMPLING

Personal inspirable dust was sampled with PAS-6 sampling heads at a flow rate of 
21/min..$^{9}$ Dust measurements were performed during the afternoon shift (1500-2300). After sampling, filters were weighed and subsequently used for antigen or endotoxin analysis. High volume samplers were used in different departments to obtain dust for the antigen analysis, which will be referred to as pooled dust. For all dust exposure measurements Whatman GF/A glass fibre filters were used.

\section{ENDOTOXIN ANALYSIS}

Endotoxin analyses were performed by the technique previously described by Attwood et $a l .{ }^{10}$ Briefly, endotoxin was extracted from filters by rocking for one hour in $10 \mathrm{ml}$ sterile, pyrogen free water. The suspension was centrifuged at $1000 \mathrm{~g}$ for 10 minutes. The endotoxin concentration was measured with the lymulus amoebocyte lysate test (Kabivitrim, Sweden).

\section{ANTIGEN ANALYSIS}

Antigen analyses were performed as described by Hollander et al. ${ }^{11}$ Briefly, antigens were extracted from the filters by homogenisation in $5 \mathrm{ml}$ phosphate buffered saline (PBS, $\mathrm{pH}$ $7 \cdot 4)$. The suspension was centrifuged at 2000 $g$ for 20 minutes. The antigen concentration was measured by enzyme linked immunosorbent assay (ELISA) inhibition. Dust collected by high volume samplers in different departments was used as the antigen source (pooled dust). Antibodies to $\mathrm{IgG}_{4}$ of 20 workers were used as the antibody source. To determine relative antigen units (RAU) three dilutions of each sample were analysed. After calculating the percentage of inhibition a logit transformation was applied and the RAU for each sample was calculated by linear regression analysis. The RAU for a sample is the reciprocal dilution which gives $50 \%$ inhibition. All samples were analysed in duplicate on different days.

\section{ANTIBODY ANALYSIS}

One week before and four weeks after the beginning of the campaign, serum was collected from the workers. IgG $_{4}$ antibodies against pooled dust were determined in all serum samples.

Specific $\mathrm{IgG}_{4}$ antibodies were measured by ELISA. A polystyrene microtitre plate (Greiner, high capacity, 655061) was coated with pooled dust in a volume of $200 \mu \mathrm{l} /$ well for 16 hours at $4^{\circ} \mathrm{C}$. Subsequently the plates were washed and incubated for 30 minutes at room temperature with assay buffer (phosphate buffered saline, $\mathrm{pH} 7 \cdot 4,0 \cdot 2 \%$ gelatin, $0.05 \%$ tween 20). Eight serial dilutions of serum samples in assay buffer were added to the wells $(200 \mu \mathrm{l})$. As controls, routinely four blanks ( $200 \mu \mathrm{l}$ assay buffer) and four positives ( $200 \mu \mathrm{l}$ pooled serum) were analysed on each plate. The plate was incubated for one hour at $37^{\circ} \mathrm{C}$. After washing with assay buffer, each well was filled with $200 \mu \mathrm{l}$ of a 1:1000 dilution of murine monoclonal anti-human
$\mathrm{IgG}_{4}$ conjugated to horseradish peroxidase in assay buffer (central laboratory for blood transfusion (CLB), The Netherlands, MH164ME). The plate was incubated for one hour at $37^{\circ} \mathrm{C}$. After subsequent washing, enzyme bound to the plate was detected by incubation with hydrogen peroxide and $\mathrm{O}$ phenylenediamine. After 30 minutes the absorbance was measured at $492 \mathrm{~nm}$ with an ELISA reader (SLT, EAR 340 AT).

All serum samples were analysed in duplicate or triplicate on different days. A small variation in results between plates was found. We corrected for this by multiplying all optical densities of a plate with a coefficient after subtraction of the mean level of the blanks on that plate. This plate specific coefficient was calculated by dividing the mean optical density of the positive control wells of all the plates by the respective mean of an individual plate. A dilution-response curve was constructed for each serum by plotting the corrected optical density against the logarithm of the serum dilution. Curve fitting was performed considering the lower half of the dilution-response curve to be parabolic. ${ }^{12}$ The $\mathrm{IgG}_{4}$ titre was defined as the reciprocal of the serum dilution which gave an optical density of $0 \cdot 25 .{ }^{13}$ This optical density was chosen, as it has previously been shown that an antibody titre based on a low optical density correlates well with the antibody concentration. ${ }^{14}$ Serum samples with an optical density smaller than 0.25 at a $1 / 20$ dilution were recorded as undetectable.

Specific IgE antibodies against pooled dust were tested for in serum samples collected four weeks after the beginning of the campaign. Specific IgE antibodies against pooled dust were measured by means of PhadezymRast (Pharmacia). Cyanogen bromide activated cellulose discs were coated with pooled dust up to $10 \mathrm{mg} / \mathrm{ml}$ as described by van der Heide et al. ${ }^{15}$ Serum $(50 \mu \mathrm{l})$ was added to a polypropylene tube containing one disc and was incubated for three hours at room temperature. After washing, discs were incubated overnight at room temperature with $50 \mu \mathrm{l}$ conjugate (rabbit monoclonal anti-human IgE conjugated to $\beta$ galactosidase). After subsequent washing, enzyme bound to the plate was detected by incubation with $200 \mu$ l substrate solution for two hours at $37^{\circ} \mathrm{C}$. The reaction was stopped with $1.0 \mathrm{ml}$ stop-solution and the absorbance was measured at $\mathbf{4 2 0}$ nm.

\section{PEAK FLOW MEASUREMENTS}

During a four week period, which started about one week before the beginning of the campaign, peak flow measurements were performed in a random sample of all workers, with mini-Wright peak flow meters. During this period, workers had to register the results in small diaries. The peak flow had to be measured four times a day; before, midway, at the end of the work shift, and once at home. During a day off the peak flow had to be measured at least three times a day. Each measurement consisted of three readings. 
Table 1 Geometric mean (GM), geometric standard deviation (GSD), and range of the personal dust concentration ( $m g / m^{3}$, $\left.n=202\right)$, relative antigen concentration $\left(10^{2} R A U / m^{3},(n=82)\right.$, and endotoxin concentration $\left(n g / m^{3}, n=89\right)$

\begin{tabular}{|c|c|c|c|c|c|c|c|c|c|c|c|c|}
\hline \multirow[b]{2}{*}{ Function } & \multicolumn{4}{|c|}{ Dust $\left(m g / m^{3}\right)$} & \multicolumn{4}{|c|}{ Antigen $\left(10^{2} R A U / m^{3}\right)$} & \multicolumn{4}{|c|}{ Endotoxin (ng/m $\left.{ }^{3}\right)$} \\
\hline & No & $G M$ & $G S D$ & Range & No & $G M$ & $G S D$ & Range & No & $G M$ & $G S D$ & Range \\
\hline $\begin{array}{l}\text { Operator, washing or grinding department } \\
\text { Operator, refinery department } \\
\text { Operator, drying department } \\
\text { Operator, fibre dehydration department } \\
\text { Starch sacker } \\
\text { Operator, damping installation } \\
\text { Operator, protein department } \\
\text { Protein sacker } \\
\text { Operator, protapec department } \\
\text { Operator, all round }\end{array}$ & $\begin{array}{l}22 \\
25 \\
16 \\
16 \\
13 \\
33 \\
16 \\
16 \\
23 \\
22\end{array}$ & $\begin{array}{r}0 \cdot 7 \\
0 \cdot 7 \\
3 \cdot 9 \\
0 \cdot 6 \\
9 \cdot 0 \\
0 \cdot 5 \\
2 \cdot 5 \\
56 \cdot 0 \\
2 \cdot 3 \\
2 \cdot 7\end{array}$ & $\begin{array}{l}2 \cdot 1 \\
2 \cdot 1 \\
2 \cdot 1 \\
1 \cdot 8 \\
2 \cdot 1 \\
2 \cdot 4 \\
6 \cdot 3 \\
5 \cdot 7 \\
3 \cdot 6 \\
6 \cdot 2\end{array}$ & $\begin{array}{l}0 \cdot 3-7 \cdot 4 \\
0 \cdot 3-3 \cdot 8 \\
0 \cdot 6-10 \cdot 9 \\
0 \cdot 3-1 \cdot 9 \\
2 \cdot 1-22 \cdot 7 \\
0 \cdot 3-13 \cdot 8 \\
0 \cdot 3-173 \\
7 \cdot 9-1160 \\
0 \cdot 3-27 \cdot 5 \\
0 \cdot 3-145\end{array}$ & $\begin{array}{r}9 \\
13 \\
7 \\
8 \\
5 \\
17 \\
8 \\
8 \\
7 \\
-\end{array}$ & $\begin{array}{l}2 \cdot 0 \\
2 \cdot 9 \\
1 \cdot 7 \\
2 \cdot 4 \\
0 \cdot 6 \\
0 \cdot 6 \\
0 \cdot 9 \\
0 \cdot 8 \\
0 \cdot 8 \\
-\end{array}$ & $\begin{array}{l}2 \cdot 3 \\
2 \cdot 3 \\
1 \cdot 6 \\
2 \cdot 6 \\
1 \cdot 0 \\
1 \cdot 2 \\
2 \cdot 3 \\
1 \cdot 6 \\
1 \cdot 6 \\
-\end{array}$ & $\begin{array}{l}0.6-6 \cdot 7 \\
0.9-9 \cdot 3 \\
0.9-3 \cdot 4 \\
0 \cdot 6-10 \cdot 2 \\
- \\
0 \cdot 6-1 \cdot 3 \\
0 \cdot 6-4.5 \\
0 \cdot 6-1.9 \\
0 \cdot 6-2.0 \\
-\end{array}$ & $\begin{array}{r}12 \\
12 \\
7 \\
5 \\
8 \\
15 \\
8 \\
8 \\
14 \\
-\end{array}$ & $\begin{array}{r}11 \cdot 5 \\
22 \cdot 9 \\
36 \cdot 1 \\
72 \cdot 0 \\
3 \cdot 4 \\
9 \cdot 2 \\
10 \cdot 3 \\
8 \cdot 6 \\
12 \cdot 6 \\
-\end{array}$ & $\begin{array}{l}2 \cdot 4 \\
2 \cdot 3 \\
3 \cdot 6 \\
3 \cdot 2 \\
1 \cdot 6 \\
2 \cdot 1 \\
2 \cdot 0 \\
1 \cdot 8 \\
2 \cdot 7 \\
-\end{array}$ & $\begin{array}{l}3 \cdot 4-54 \cdot 4 \\
3 \cdot 8-105 \\
3 \cdot 8-137 \\
24 \cdot 5-484 \\
1 \cdot 6-7 \cdot 4 \\
2 \cdot 5-27 \cdot 8 \\
2 \cdot 7-19 \cdot 5 \\
3 \cdot 6-24 \cdot 4 \\
3 \cdot 4-110 \\
-\end{array}$ \\
\hline
\end{tabular}

\section{Results}

EXPOSURE MEASUREMENTS

We obtained 202 personal inspirable dust samples and selected half of the samples at random, in which the antigen concentration was analysed. The endotoxin concentration was analysed in the other half. Table 1 summarises the results of the personal measurements. Based on these measurements the workers were divided into two groups with different exposure characteristics. The average dust exposure of protein sackers was extremely high $\left(56 \mathrm{mg} / \mathrm{m}^{3}\right)$. This dust seems, however, to be biologically inactive because low concentrations of antigen $\left(0 \cdot 8.10^{2}\right.$ $\left.\mathrm{RAU} / \mathrm{m}^{3}\right)$ and endotoxins $\left(8.6 \mathrm{ng} / \mathrm{m}^{3}\right)$ were found in these dust samples. Exposure to biologically inactive dust was also found among starch sackers, operators of the protapec and protein department, and operators of the damping installation. The exposure of these workers can be characterised as an exposure to relatively high dust concentrations $(0 \cdot 5-56$ $\left.\mathrm{mg} / \mathrm{m}^{3}\right)$, but low antigen $\left(0 \cdot 6-0 \cdot 9.10^{2}\right.$ $\mathrm{RAU} / \mathrm{m}^{3}$ ) and endotoxin concentrations $\left(3.4-12.6 \mathrm{ng} / \mathrm{m}^{3}\right)$. The second group consists of workers from the washing and grinding, refinery, drying, and fibre dehydration departments. This group is exposed to relatively high antigen $\left(1 \cdot 7-2 \cdot 9.10^{2} \mathrm{RAU} / \mathrm{m}^{3}\right)$ and endotoxin concentrations $\left(11.5-72 \mathrm{ng} / \mathrm{m}^{3}\right)$, but low dust concentrations $\left(0 \cdot 6-3.9 \mathrm{mg} / \mathrm{m}^{3}\right)$.

Table $2 \mathrm{IgG}_{4}$ titres of the positive workers, before the campaign, during the campaign, and the change between these two periods

\begin{tabular}{ccc}
\hline $\begin{array}{l}I g G_{4} \\
\text { before }\end{array}$ & $\begin{array}{l}I g G_{4} \\
\text { during }\end{array}$ & $\begin{array}{l}I g G_{4} \\
\text { change }\end{array}$ \\
\hline 44 & 27 & -17 \\
23 & 14 & $-9 \cdot 0$ \\
28 & 21 & $-7 \cdot 0$ \\
$2 \cdot 4$ & $2 \cdot 1$ & $-0 \cdot 30$ \\
$0 \cdot 74$ & $0 \cdot 51$ & $-0 \cdot 23$ \\
$0 \cdot 39$ & $0 \cdot 35$ & $-0 \cdot 04$ \\
$0 \cdot 00$ & $0 \cdot 20$ & $0 \cdot 20$ \\
$0 \cdot 00$ & $0 \cdot 24$ & $0 \cdot 24$ \\
$0 \cdot 25$ & $0 \cdot 52$ & $0 \cdot 27$ \\
$0 \cdot 00$ & $0 \cdot 29$ & $0 \cdot 29$ \\
$0 \cdot 00$ & $0 \cdot 48$ & $0 \cdot 48$ \\
$0 \cdot 00$ & $0 \cdot 62$ & $0 \cdot 62$ \\
$3 \cdot 7$ & $7 \cdot 3$ & $3 \cdot 6$ \\
$0 \cdot 21$ & $6 \cdot 9$ & $6 \cdot 7$ \\
$0 \cdot 38$ & 10 & $9 \cdot 6$ \\
27 & 37 & 10 \\
$5 \cdot 7$ & 17 & 11 \\
44 & 56 & 12 \\
$4 \cdot 0$ & 23 & 19 \\
16 & 47 & 31 \\
\hline
\end{tabular}

IMMUNOLOGICAL RESPONSE TO AIRBORNE CONTAMINANTS

Blood samples were taken from $53(72 \%)$ workers employed in the production part of the plant. Of these workers, five were sampled one week before the beginning of the campaign, and seven were sampled four weeks after the beginning of the campaign. A total of 41 workers were sampled both before and during the campaign.

None of the 48 serum samples collected had detectable specific IgE against pooled dust. In 20 of these serum samples (42\%) specific $\mathrm{IgG}_{4}$ antibodies against pooled dust were found. Of those 20 workers, specific $\mathrm{IgG}_{4}$ antibodies before the campaign were also measured (table 2). Fourteen of them showed an increase in $\mathrm{IgG}_{4}$ antibody titre after the beginning of the campaign and six showed a decrease. Based on the exposure measurements the workers were divided into a low or high antigen exposed group. The all round operators could not be classified in one of these groups and were omitted from analysis. Figure 1 shows the distribution of specific $\mathrm{IgG}_{4}$ antibody concentrations of the workers. Compared with the workers with low antigen exposure, more workers with a high antigen exposure had high $\mathrm{IgG}_{4}$ antibody titres and less had $\mathrm{IgG}_{4}$ antibody titres below the detection limit.

\section{RESPIRATORY SYMPTOMS AND PEAK FLOW MEASUREMENTS}

Table 3 presents respiratory symptom prevalence. Forty four per cent of the production workers experienced one or more respiratory symptoms. The most common was occasional wheezing (32\%).

A sample of 22 persons recorded their peak flow variation during a four week period. Of these, three workers showed poor peak flow

Table 3 Prevalence of respiratory symptoms of the potato starch production workers $(n=41)$

\begin{tabular}{ll}
\hline Respiratory symptoms & $\begin{array}{l}\text { Total } \\
\text { prevalence(\%) }\end{array}$ \\
\hline Daily cough >3 months/y & $4 \cdot 9$ \\
Daily phlegm >3 months/y & - \\
Shortness of breath & $2 \cdot 4$ \\
Wheezing & 32 \\
Wheezing for more than 1 week in past 2 years $9 \cdot 8$ \\
Attacks of tightness of chest (asthma) & $9 \cdot 8$ \\
One or more of these symptoms & 44 \\
\hline
\end{tabular}


Figure $1 \mathrm{IgG}_{4}$ titres of the workers of the production department before and during the campaign for the low and high exposure to antigen categories. Values below the line were not detectable.

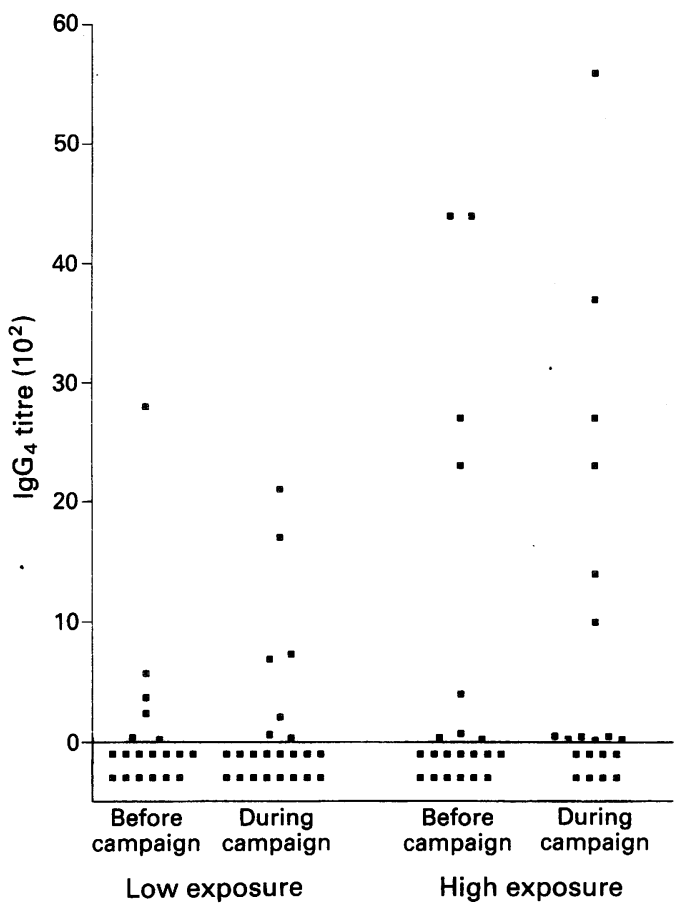

recordings during this period and these records could not be used. Three of the 22 workers showed a maximum variation in peak flow of less than $5 \%$. Nine workers showed a maximum variation in peak flow between $5 \%$ and $10 \%$. Five records showed a variation in peak flow between $10 \%$ and $20 \%$, but without an apparent work related pattern. Two workers showed a clear and strong decline in peak flow patterns related to exposure during work (fig 2). Figure 2(A) illustrates the peak flow pattern of an operator of the fibre dehydration department. After the start of the campaign (17 August), the pattern shows a deterioration of the peak flow almost every working day. The recovery is substantial by the next day and this pattern repeated itself each day. Such daily patterns are usually associated with immediate asthmatic reactions. ${ }^{16}$ In the serum sample of this worker no specific $\mathrm{IgE}$ or $\mathrm{IgG}_{4}$ antibodies against pooled dust could be detected.

Figure 2(B) shows a pattern of an operator of the protapec department. The record shows a progressive daily deterioration after the beginning of the campaign with no recovery during the days off work. Daily patterns are not seen when recovery takes longer than two to three days. It has been shown in other studies that some workers appear to reach a plateau after which no further deterioration occurs. ${ }^{16}$ This worker had no specific IgE antibodies against pooled dust, but had a specific $\mathrm{IgG}_{4}$ titre of $2 \cdot 1.10^{2} \mathrm{RAU} / \mathrm{m}^{3}$.

\section{Discussion}

The main objective of this study was to investigate the relation between bioaerosol exposure in the potato starch producing industry and respiratory effects. In this study we measured exposure to occupational dust, antigen,

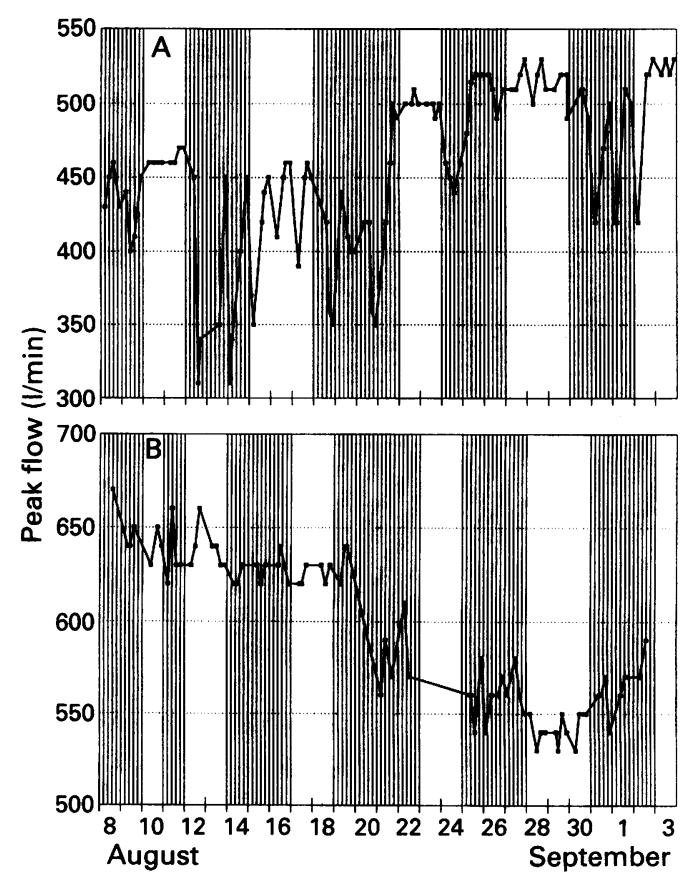

Figure 2 Peakflow pattern of an operator, fibre dehydration department $(A)$, and an operator, protapec department (B). The peak flow was recorded during a four week period. The campaign started on 17 August. The period at work is shaded.

and endotoxin at different locations in factory. Respiratory effects were studied by registering work related respiratory symptoms, by measuring peak flow over a three to four week period and by measuring specific antibody concentrations. Recently, health effects like chest tightness and wheeze have been described among workers in a related industry, the sugar beet processing industry. ${ }^{6}$ Here microbiological and antigen air sampling showed considerable contamination of bioaerosols in the atmosphere around the beet slicers. It was concluded that exposure to bioaerosols could be the cause of the acute respiratory symptoms. Similarly it is possible that potato proteins can cause allergic reactions. ${ }^{17} 18$

Based on the quantity of dust, antigens, and endotoxins in the air and production characteristics the workers were divided into two exposure categories with a considerable quantitative and qualitative difference in exposure. Exposure of one group consisted mainly of dust. The exposure to antigens and endotoxins prevailed in the second group. Applying the current threshold limit value (TLV) for total nuisance dust in The Netherlands of $10 \mathrm{mg} / \mathrm{m}^{3}$ over an eight hour period, dust exposure of operators of the first group regularly exceeded this value. These high dust concentrations were found mainly near the sacking machines and during cleaning activities. This dust seemed biologically inactive, because low antigen and endotoxin concentrations occurred in this dust. In the protein department and the protein sacking department the major constituents of dust are potato proteins. ${ }^{11}$ High dust concentrations 
were found in these departments and therefore high exposure to antigens was expected. Only low antigen concentrations were found in the air, however. This may be due to the processing of proteins. Proteins were heated to be harvested. The denatured proteins lost their antigenic activity, as has been described in other studies. ${ }^{817}$ In those studies patients with a positive skin prick test against extracts made from fresh potatoes had a negative reaction to an extract of cooked potatoes.

In the second exposure group antigen concentrations were high because potato proteins were not denatured. As previously described by Hollander et al, ${ }^{11}$ potato extract gave a $100 \%$ inhibition in the ELISA assay. Also, dilution lines of pooled dust and purified potato extract showed similar slopes in the inhibition assay, indicating that antigenic activity was caused by potato antigens. Inhibition with other purified potential allergen sources from the work environment, such as endotoxins, were negative, indicating that potato antigens were the only antigen sources present in this working environment.

In the second exposure group exposure to endotoxin was high with an average exposure of $72 \mathrm{ng} / \mathrm{m}^{3}$ for the operators of the fibre dehydration department. Endotoxin concentrations were similar to those found in environments known to be heavily contaminated, such as swine confinement buildings. In a study undertaken by our group an average concentration of $128 \mathrm{ng} / \mathrm{m}^{3}$ was found. ${ }^{10}$ Endotoxins might play a part as a potential cause of the health effects found. No TLV for occupational endotoxin exposure exists. Experimental studies in humans and other species have shown exposure dependent acute lung function changes after inhalation of endotoxin. Castellan et al found no acute changes in $\mathrm{FEV}_{1}$ with a concentration of 9 $\mathrm{ng} / \mathrm{m}^{3}$ of endotoxin in the air in people with respiratory symptoms. ${ }^{19}$ Based on these and other results Palchak et al suggested a TLV of $10-30 \mathrm{ng} / \mathrm{m}^{3} .{ }^{20}$ Milton et al recently suggested a TLV of $0.3-3 \mathrm{ng} / \mathrm{m}^{3}$. ${ }^{21}$ They based this on results presented by Kennedy et al, who found a statistically significant exposureresponse relation between endotoxin exposure and baseline $F_{E V}$ in a cross sectional study among cotton workers. ${ }^{22}$ From this finding they suggested that endotoxin may have important chronic pulmonary effects at concentrations that are not necessarily associated with acute airflow limitations. Compared with the study presented by Kennedy et $a l,{ }^{22}$ stronger effects of chronic endotoxin exposure on lung function were described in a study among workers in the animal feed industry. ${ }^{23}$

In our study there were raised specific $\operatorname{IgG}_{4}$ antibodies among workers with high antigen exposure. This was also the situation in other studies in which $\mathrm{IgG}_{4}$ antibodies against bioaerosols were considered to be indicators of exposure. ${ }^{25-28}$ Occupational exposure to high concentrations of these aerosols results in highly specific IgG $_{4}$ antibodies in symptomatic as well as in symptom free workers.
According to van der Zee and Aalberse greatly increased titres of $\mathrm{IgG}_{4}$ antibodies were found after prolonged antigenic stimulation. ${ }^{28}{ }^{29}$ In this study, however, four weeks of exposure was sufficient to raise the $\mathrm{IgG}_{4}$ antibody titre, indicating exposure to high concentrations of antigen.

Antigenic stimulation to potatoes can cause a potato allergy. ${ }^{78}$ In our study exposure to bioaerosols was related to effects on health. This was reflected by the increased prevalence of wheezing and the work related decline in peak flow of two workers. These two cases indicate that the presence of bioaerosols can provoke obstructive reactions, resembling an allergic asthmatic reaction. Mechanisms mediated by IgE were not supported by IgE measurement against extracts of pooled dust, which showed negative titres in both workers. According to Newman Taylor and Venables, the relation between immunological and airway responsiveness is not fixed and varies depending on the nature of the agent. ${ }^{24}$ It will be difficult to determine the actual risk for developing this specific type of asthma. Some workers in this industry are only employed during the campaign, lasting from August until April. The rest of the year they are employed in other industries. Those who develop asthma will probably not return the next year and it seems plausible that a strong healthy worker effect is present.

Summarising the results, the exposure to bioaerosols in this potato starch producing plant can cause effects to health in some workers. The responsible agent could not be identified, but bioaerosols generated in the potato starch seem to play an important part. As mentioned before, endotoxin concentrations were extremely high in some areas of the plant. It is possible that endotoxins might contribute to the health effects, or indeed are the cause. Additional studies are needed to investigate the nature and cause of respiratory effects in potato processing. One direction of research could consist of a more detailed description of clinical manifestations among those with severely impaired patterns of peak flow or severe respiratory symptoms.

This study was supported by a grant of the Dutch Directorate of Labour of the Ministry of Social Affairs and Employment. We thank Janneco Pothuis and Bert Denen for their help collecting data and Sicco van der Heide for laboratory support in the measurement of IgE against the dust samples.

1 Pickering CAC. A seven-year survey of allergic occupational lung disease in the United Kingdom. European fournal of Respiratory Diseases 1980;61:137-49.

Parkes WR. Occupational lung disorders. 2nd ed. London: Butterworths, 1982.

3 Rylander $R$. Lung diseases caused by organic dusts in the farm environment. Am $\mathcal{F}$ Ind Med 1985;10:221-7.

4 Dutkiewicz J, Olenchock SA, Sorenson WG. Levels of bacteria, fungi, and endotoxin in bulk and aerosolized bacteria, fungi, and endotoxin in bulk and aeroso

5 Chan-Yeung M. Occupational Asthma. Chest 1990;98 (Suppl):148-61.

6 Forster HW, Crook B, Platts BW, Lacey J, Topping MD. Investigation of organic aerosols generated during sugar beet slicing. Am Ind Hyg Assoc f 1989;50:44-50. 
7 Pearson B. Potato sensitivity, an occupational allergy in housewives. Acta Allergologica 1966;21:507-14

8 Quirce S, Gomez LD, Hinojosa M, Cuevas M, Urena V, Rivas MF, et al. Housewives with raw potato-induced bronchial asthma. Allergy 1989;44:532-6

9 Kuile WM ter. Vergleichungsmessungen mit verschiedenen Geraten zur Bestimmung de nen Geraten zur Bestimmung de Gesamtstaubkonzentration am A

10 Attwood P, Brouwer R, Ruigewaard P, Versloot P, Wit R de, Heederik D, Boleij JSM. A study of the relationship between airborne contaminants and environmental factors in Dutch swine confinement buildings. Am Ind Hyg Assoc $\mathcal{F}$ 1987; 48:745-51.

11 Hollander A, Heederik D, Pothuis J. Quantification of antigenic aerosols levels in the potato starch producing industry. Annals Occup Hyg 1993 (in press.)

12 Kurstak E. Progress in enzyme immunoassays: production of reagents, experimental design, and interpretation. of reagents, experimental design, and interpreta

13 Topping MD, Forster HW, Ide CW. Respiratory allerg and specific immunoglobulin $\mathrm{E}$ and immunoglobulin $\mathrm{G}$ antibodies to reactive dyes used in the wool industry. $f$ Occup Med 1989;31:857-62.

14 Nimmo GR, Lew AM, Stanley CM, Steward MW Influence of antibody affinity on the performance of different antibody assay. $\mathcal{f}$ Immunol methods 1984;72:177-87.

15 Heide $S$ van der, Kauffman HF, Vries $K$ de. Measurement of specific IgE and IgG antibodies against Aspergillus fumigatus antigen in patient sera by use of enzyme immunoassays: Influence of different procedures of antigen immobilization. $₹$ Allergy Clin Immunol 1984;73:813-8.

16 Burge PS. Single and serial measurements of lung function in the diagnosis of occupational asthma. Eur $f$ Respir Dis 1982;63 (suppl 123):47-59.

17 Nater JP, Zwartz MD, Zwartz JA, Wageningen D. Atopic allergic reactions due to raw potato. foumal of Allergy
1967;40:202-5

18 Castells MC, Pascual C, Esteban M, Ojeda JA. Allergy to white potato. $₹$ Allergy Clin Immunol 1986;78:1110-4

19 Castellan RM, Olenchock SA, Kinsley KB, Hankinson JL Inhaled endotoxin and decreased spirometric values. $N$ Engl Y Med 1987;10:605-9.

20 Palchak RB, Cohen R, Ainslie M, Hoerner CL. Airborne endotoxin associated with industrial-scale production of protein products in gram-negative bacteria. Am Ind Hyg Assoc $\mathcal{F}$ 1988;44:420-1.

21 Milton DK, Christiani DC, Greaves IA. Letter to the editor. Am Ind Hyg Assoc ₹f 1989;50:594-6.

22 Kennedy SM, Christiani DC, Eisen EA, Wegman DH, Greaves IA, Olenchock SA, et al. Cotton dust and endotoxin exposure-response relationship in cotton textile workers. Am Rev Respir Dis 1987;135:194-200.

23 Smid T, Heederik D, Houba R, Quanjer PhH. Dust and endotoxin related respiratory effects in the animal feed industry. Am Rev Respir Dis 1992;146:1474-9.

24 Newman Taylor AJ, Venables KM. Clinical and epidemiological methods in investigating occupational asthma. Clinical Immunology and Allergy 1984;4:3-17.

25 Katila ML, Ojanen TH, Mantyjarvi RA. Significance of IgG antibodies against environmental microbial antigen in a farming population. Clin Allergy 1986;16:459-67.

26 Virtanen T, Vilhunen P, Husman K. Sensitization of dairy farmers to bovine antigens and effects of exposure on specific IgG and IgE titres. Int Arch Allergy Appl Immunol 1988;87:171-7.

27 Platts-Mill AE, Longbottom J, Edwards J, Cockroft A Wilkins S. Occupational asthma and thinitis related to laboratory rats: serum $\mathrm{Ig} G$ and $I g E$ antibodies to the rat laboratory rats: serum IgG and IgE antibodies to the rat
urinary allergen. $f$ Allergy Clin Immunol 1987; urinary al

$28 \mathrm{Zee}$ JS van der, Aalberse RC. The role of IgG in immediate-type hypersensitivity. Eur Respir $₹$ 1991;4:91-6.

29 Zee JS van der, Aalberse RC. The role of IgG. In: Lesso MH, Lee TH, Kemeny DM. Allergy: an international textbook. London: John Wiley 1987:49-67.

\section{Vancouver style}

All manuscripts submitted to Occup Environ Med should conform to the uniform requirements for manuscripts submitted to biomedical journals (known as the Vancouver style.)

Occup Environ Med, together with many other international biomedical journals, has agreed to accept articles prepared in accordance with the Vancouver style. The style (described in full in the $B M \mathcal{F}, 24$ February $1979, \mathrm{p}$ 532) is intended to standardise requirements for authors.

References should be numbered consecutively in the order in which they are first mentioned in the text by Arabic numerals above the line on each occasion the reference is cited (Manson ${ }^{1}$ confirmed other reports $^{2-5}$. . .). In future references to papers submitted to Occup Environ Med should include: the names of all authors if there are seven or less or, if there are more, the first six followed by et al; the title of journal articles or book chapters; the titles of journals abbreviated according to the style of Index Medicus; and the first and final page numbers of the article or chapter. Titles not in Index Medicus should be given in full.

Examples of common forms of references are:

1 International Steering Committee of Medical Editors, Uniform requirements for manuscripts submitted to Uniform requirements for manuscripts submitt
biomedical journals. $B r M e d ~$
I

2 Soter NA, Wasserman SI, Austen KF. Cold urticaria: release into the circulation of histamine and eosinophil chemotactic factor of anaphylaxis during cold challenge. N Engl f Med 1976;294:687-90.

3 Weinstein L, Swartz MN. Pathogenic properties of invading micro-organisms. In: Sodeman WA Jr, Sodeman WA eds. Pathologic physiology, mechanisms of disease. Philadelphia: $\mathbb{W}$ B Saunders, 1974:457-72. 